\title{
KOMODIFIKASI UPACARA NGARAS DAN NGIBAKAN ADAT SUNDA DI KOTA BANDUNG
}

\section{COMMODIFICATION OF NGARAS AND NGIBAKAN CEREMONY SUNDANESE IN BANDUNG}

\author{
Muhamad Irfan Maulana Sidik, Sri Rustiyanti, Imam Setyobudi \\ alfarosidik@gmail.com \\ Prodi Antropologi Budaya, Fakultas Budaya dan Media \\ Institut Seni Budaya Indonesia Bandung \\ Artikel diterima: 22 Oktober 2020 || Artikel direvisi: 9 November 2020 | Artikel disetujui: 13 November 2020
}

\begin{abstract}
ABSTRAK
Upacara tradisi ngaras dan ngibakan merupakan suatu tradisi yang dilakukan sebelum pelaksanaan hari pernikahan. Upacara ini, dilaksanakan oleh masyarakat Sunda termasuk pada masyarakat Sunda di Kota Bandung sebagai suatu cara yang dipercaya agar prosesi pernikahan dapat berjalan lancar. Dalam perkembangan era globalisasi, tradisi tersebut mengalami perubahan diakibatkan masyarakat Kota Bandung yang mudah mendapatkan arus globalisasi sehingga masyarakat lebih menyukai produk jasa yang lebih efisien dan praktis sebagai ciri masyarakat modern. Hal ini berdampak pada munculnya penyedia jasa yang memodifikasi tradisi ngaras dan ngibakan dengan mengikuti permintaan pasar untuk mendapatkan nilai komoditas maksimal.

Tulisan ini, merupakan deskripsi analisis dengan menggunakan metode penelitian kualitatif. Adapun teori yang digunakan, yaitu komodifikasi. Penelitian ini, bertujuan untuk menggali sejauh mana proses komodifikasi serta dampak yang ditimbulkan terhadap masyarakat Sunda Kota Bandung itu sendiri.
\end{abstract}

Kata Kunci : Komodifikasi, Upacara Tradisi, Ngaras dan Ngibakan

\section{ABSTRACT}

The ngaras and ngibakan ceremony is a tradition that is carried out before entering the wedding day. This ceremony, carried out by the Sundanese people in the city of Bandung as a trusted way for the wedding procession to run smoothly. In the development of the era of globalization, the tradition has changed due tothe people of the city of Bandung who are easy to get the flow of modernization so that people prefer service products that are more efficient and practical. This has resulted in the emergence of service providers who modify the ngaras and trap traditions that follow market demand to get maximum commodity value.

This research, is a description of the analysis using qualitative research methods. The theory used is the Commodification. This study aims to explore the process of commodification and its impact on the Sundanese people of Bandung.

Keywords: Commodification, Tradition Ceremony, Ngaras and Ngibakan

\section{PENDAHULUAN}

Tradisi menurut Sheils (dalam Syam 2005: 277-278) bukanlah sesuatu yang diam karena diwariskan dari generasi ke generasi sehingga dapat mengakibatkan terjadi perubahan-perubahan baik dari skala besar maupun kecil terhadap tradisi tersebut. Perubahan tradisi ini bisa disebabkan oleh beberapa faktor yang salah satunya perubahan yang disebabkan pada masyarakat tradisi menjadi masyarakat modern sehingga menimbulkan suatu proses modifikasi yang merupakan bentuk penyesuaian dengan kebutuhan masyarakatnya itu sendiri. Modifikasi ditujukan sebagai suatu cara berpikir bagaimana sebuah tradisi dapat dilakukan dengan lebih mudah serta memiliki pengemasan yang lebih menarik dari pada sebelumnya. 
Modifikasi ini dapat dikaitkan dengan proses komodifikasi apabila telah terdapat nilai tukar di dalamnya, yang merupakan sebuah bentuk kreativitas yang dilakukan pemilik modal terhadap sebuah produk barang maupun jasa yang muara tujuannya adalah pasar sehingga dapat menghasilkan nilai komoditas maksimal. Salah satu bagian dari rangkaian upacara pernikahan adat Sunda yang mengalami perubahan itu adalah materi upacara ngaras dan ngibakan yang akan dijadikan objek penelitian dengan menggunakan analisis komodifikasi.

Adapun penelitian terdahulu yang berkaitan dengan komodifikasi, antara lain Dewi (2016) mengungkapkan seni tradisional Barong yang bersifat sakral, saat ini berubah menjadi sebuah tontonan hiburan dalam industri pariwisata yang bernilai komersial dalam aspek seni pertunjukannya. Penelitian ini menunjukan bahwa telah terjadi komodifikasi terhadap tari Barong yang ada di Bali, yang semula sangat sakral menjadi seni pertunjukan yang menghasilkan komoditi yang bernilai komersial, penelitian Yulianti (2011) terhadap upacara ritual Tabot sebagai bentuk produk pemasaran pariwisata tradisi daerah lokal dengan cara komodifikasi di Provinsi Bengkulu. Yulianti memperlihatkan proses terjadinya komodifikasi terhadap upacara Tabot, dalam hal ini, Dinas Pariwisata bekerja-sama dengan kerukunan keluarga Tabot mengembangkan upacara religi Tabot sebagai komoditas pariwisata yang bernilai komersial.

Pada dasarnya, setiap tradisi upacara ritual secara umum terdapat dua kategori. Upacara ritual yang bersifat publik dan privat, publik sendiri menurut Herbert Blumer (dalam Sastropoetro, 1987) adalah sekelompok orang yang tertarik pada suatu isu serta berusaha dalam menghadapi dan mengatasi isu tersebut. Dalam hal ini upacara ritual yang bersifat publik adalah upacara ritual yang dilakukan oleh sekelompok orang sebagai cara yang dipercaya dapat mengatasi suatu masalah dalam suatu kelompok tersebut yang biasanya memiliki ciri khas dimana ritual tersebut berada, dalam pelaksanaanya dapat disaksikan oleh masyarakat umum. Sedangkan privasi dikatakan oleh Bates 1964 (dalam Wicaksono 2018:30) mengatakan bahwa privasi adalah merupakan batas pilihan untuk menghindarkan seseorang dari keterlibatannya dengan orang lain yang bersifat umum atau publik, dalam pengertian privasi ini merupakan kemampuan satu atau sekelompok individu untuk menyimpan urusan personalnya dari publik.

Beberapa contoh kategori upacara ritual yang bersifat publik publik adalah sekaten yang berkaitan dengan peringatan hari kelahiran Nabi Muhammad SAW di Yogyakarta, tolak bala mengusir gangguan gaib yang kemungkinan dapat menyerang sebuah kampung atau desa dan pura pada tari Barong di Bali, dan upacara ritual Tabot di Bengkulu yang merupakan upacara berkabung atas gugurnya Sayid Agung Husein Bin Ali Bin Abi Thalib, salah seorang cucu Nabi Muhammad SAW. Sedangkan kategori upacara ritual yang bersifat privat seperti upacara pernikahan Pangadangan pada suku-bangsa Ogan Sumatera Selatan, Kawin Culik pada suku-bangsa Sade, atau adol Dawet suku-bangsa Jawa serta beberapa adat pernikahan di berbagai daerah di Indonesia.

Pada sejumlah penelitian terdahulu yang sudah ditunjukkan, maka penelitian tentang komodifikasi masih terbatas pada fenomena upacara ritual yang bersifat publik. Sementara itu, upacara ritual yang bersifat private belum pernah dilakukan dengan analisa komodifikasi. Padahal, gejala komodifikasi bukan saja terbatas pada upacara ritual yang bersifat publik akibat adanya sentuhan industri pariwisata. Akan tetapi, gejala komodifikasi juga melanda upacara ritual yang bersifat privat termasuk pada upacara pernikahan dalam adat- istiadat Sunda.

Oleh karena itu, didasarkan pada pertimbangan bahwa fenomena upacara ritual yang bersifat privat belum pernah diteliti menurut analisa komodifikasi, maka peneliti menganggap permasalahan ini menarik untuk dilakukan penelitian. Dimana fenomena gejala komodifikasi menyentuh pula pada bentukbentuk upacara tradisi yang bersifat privat itu telah terjadi pada saat ini. Sehingga diharapkan dapat menjawab masalah penelitian seperti bagaimana proses komodifikasi yang terjadi terhadap upacara ngaras dan ngibakan dalam model pernikahan adat-istiadat kebudayaan Sunda pada sebuah penyedia jasa; dan bagaimana dampak komodifikasi yang terjadi terhadap upacara ngaras dan ngibakan bagi 
masyarakat Sunda di Kota Bandung?

\section{METODA}

Dalam menjawab permasalahan yang ingin diteliti, maka dibutuhkan sebuah metode untuk menjalankan penelitian. Metode yang digunakan penulis pada penelitian ini adalah penelitian kualitatif, menggunakan prosedur penelitian yang menghasilkan data deskriptif berupa kata-kata tertulis atau lisan dari orang orang dan perilaku yang diamati (Moleong, 2012:4).

Pemilihan pendekatan kualitatif karena sesuai dengan sifat dan masalah serta tujuan peneliti yang ingin memperoleh gambaran yang nyata terkait dengan komodifikasi upacara ngaras dan ngibakan pada penyedia jasa kesenian di Kota Bandung. Dengan menggunakan metode ini memudahkan peneliti untuk mengetahui alur dan kronologis suatu peristiwa secara runtut. Selain itu deskripsi yang dihasilkan oleh kualitatif juga memudahkan peneliti dalam menggali data dengan maksimal. Data yang didapat umumnya berupa kata-kata, yang menjelaskan bagaimana bentuk komodifikasi ini terjadi, peneliti ingin mencari tahu rangkaian, bentuk, nilai komoditas serta masyarakat pelaku dari tradisi ngaras dan ngibakan dari masa ke masa, sampai pada munculnya komodifikasi pada tradisi tersebut, dan tentunya, para pengguna jasanya (customer, client, user).

Penelitian ini menggunakan tahapantahapan pelaksanaan penelitian yang di dalamnya meliputi aspek-aspek sebagai berikut:

\section{A. Lokasi Penelitian}

Penelitian ini dilakukan peneliti di lokasi para pemangku hajat salah satu group kesenian yang berada di wilayah Buah Batu Kota Bandung yang akan diklasifikasikan terlebih dahulu ke dalam enam kecamatan, sehingga dapat mempermudah peneliti dalam proses pengambilan data untuk mengetahui kalangan masyarakat mana yang menggunakan jasa upacara ngaras dan ngibakan ini.

Peneliti mengambil sampel penelitian pada group kesenian Mitra Seni Inten Dewangga atau yang biasa disebut MSID itu sendiri merupakan sebuah kelompok penyedia Jasa Kesenian yang didirikan pada tanggal 22 Oktober 1996 yang dipimpin oleh Bapak Iwa
Permana S.Sen dan masih tetap eksis hingga saat ini. Dimana produk kesenian yang terdapat pada MSID selalu memberikan pengemasan-pengemasan yang baik, dengan berbagai inovasi dan modifikasi serta kejelian dalam mengatur durasi sehingga tidak membosankan para klien atau pemangku hajat yang menggunakan jasa dari MSID ini.

Adapun jasa yang disediakan oleh Mitra Seni Inten Dewangga itu sendiri di antaranya pagelaran hiburan tarian tradisional, pagelaran musik tradisional, prosesi pernikahan, prosesi khitanan, prosesi peresmian gedung dan peluncuran produk, termasuk upacara adat ngaras dan ngibakan.

\section{B. Teknik Pengumpulan Data}

1. Studi Lapangan

Teknik yang dilakukan peneliti untuk mengumpulkan data primer antara lain observasi partisipan, wawancara tidak terstruktur, dan dokumentasi. Sehingga dalam penelitiannya peneliti mendapatkan data mengenai objek yang diteliti pada upacara ngaras dan ngibakan di Mitra Seni Inten Dewangga.

a. Observasi Partisipan

Peneliti mengamati dan mencatat secara detail dalam setiap upacara ngaras dan ngibakan yang dilaksanakan, khususnya pada bentuk dan rangkaian yang sedang berlangsung.

Metode observasi yang digunakan peneliti adalah observasi partisipan sehingga peneliti memperoleh data lengkap mengenai proses upacara ngaras dan ngibakan, pemangku hajat pada mitra seni Inten Dewangga secara langsung yang nantinya data ini dapat dijadikan sebagai dasar untuk mendapatkan informasi yang lebih terperinci dan akurat.

\section{b. Wawancara}

Wawancara ini mengharuskan membuat kerangka dan garis besar pokokpokok yang dirumuskan tidak ditanyakan secara berurutan. Dalam teknik ini peneliti akan menuliskan dan merekam hasil wawancara menjadi sebuah catatan hasil wawancara. Pemilihan informan yang berhubungan langsung dengan fokus permasalahan dalam penelitian yang dapat memberi jawaban sebenar-benarnya sehingga 
hasil penelitian dapat diuji kebenarannya. Dalam penelitian ini informan terdiri dari: pemilik penyedia jasa, pemandu upacara, masyarakat yang terlibat, serta penyedia jasa dekorasi yang mengetahui mengenai perubahan prosesi upacara ngaras dan ngibakan ini, dan juga, pengguna jasanya (klien) Mitra Seni Inten Dewangga yang umumnya tinggal tersebar pada perumahan-perumahan elit di Kota Bandung.

\section{c. Dokumentasi}

Teknik pengambilan data berupa dokumentasi ini digunakan dalam penelitian sebagai sumber data yang bermanfaat untuk kelengkapan penelitian yang dapat dilihat lebih jelas pada segi tekstualitasnya.

\section{d. Analisis Data}

Data yang sudah terkumpul kemudian diolah dengan cara diklasifikasikan dan dianalisis untuk menemukan jawaban dari permasalahan yang terdapat dalam penelitian ini. Teori yang dipakai dalam penelitian ini adalah komodifikasi sebagai pijakan peneliti dalam menganalisis kasus yang terjadi pada komodifikasi upacara ngaras dan ngibakan pada MSID di Kota Bandung. Analisis data yang digunakan dengan maksud untuk mensistematisasi data ke dalam bentuk yang mudah dipahami ke dalam tiga alur kegiatan yang terjadi bersamaan: reduksi data, penyajian data, penarikan simpulan, dan verifikasi (Miles \& Huberman, 1992:16).

\section{HASIL DAN PEMBAHASAN}

\section{A. Asal-usul Ngibakan dan Ngaras}

Berbagai sumber literatur tentang adatistiadat perkawinan orang Sunda seperti Modana karya R.H. Uton Muchtar (1997) dan informan yang diwawancara, tidak satupun, yang dapat mengetahui pasti kapan upacara ngibakan ini pertama kali dilaksanakan sehingga kemudian menjadi sebuah tradisi. Namun diperkirakan tradisi tersebut sudah ada sejak dahulu dan terus diturunkan dari generasi ke generasi sebagai proses memandikan pengantin sembari diiringi doa.

Ngibakan itu sendiri menurut Rosidi (2006: 128) adalah prosesi memandikan calon pengantin yang memiliki makna pembersihan secara lahir maupun batin bagi calon pengantin tersebut sebelum melangsungkan pernikahan dengan menggunakan air tujuh sumber dicampur bunga tujuh rupa atau kembang setaman, sebagai simbol penyucian diri sebelum memulai mahligai rumah tangga yang dilakukan sebelum hari pernikahan. Jadi dapat dikatakan upacara tradisi ngibakan lebih dahulu ada sebelum munculnya prosesi upacara ngaras.

Ngaras sendiri merupakan ide kreatif seorang budayawan Sunda bernama Rd. Hidayat Suryalaga yang muncul untuk melengkapi rangkaian upacara pra pernikahan Sunda pada tahun 1975 dan pertama kali dipresentasikan pada pernikahan salah satu anak gubernur Jawa Barat Haji Aang Kunaefi.

Ngaras dalam bahasa Jawa artinya sungkem, munjungan. Kata Ngaras berasal dari kata raras yang artinya senang, indah, dan haru dalam bahasa Kawi. Dalam bahasa Sunda ada kata ngaraas yang berasal dari kata raas yang artinya menyeberangi air yang dangkal. Kata ngaras tersebut berkaitan dengan air. Namun Rd. Oesman Sadli Sumadilaga memiliki pendapat yang berbeda mengenai arti ngaras. Beliau mengatakan bahwa ngaras memiliki arti sebagai prosesi mencuci atau membasuh telapak kaki kedua orang tua (Suhendi, 2004:10).

\section{B. Struktur dan BentukUpacaraNgaras dan Ngibakan}

Pada bagian ini akan diuraikan mengenai deskripsi upacara ngibakan dan ngaras dalam dua aspek, yang versi lama (awal) dan versi pengembangan (baru). Peneliti bermaksud membandingkan di antara keduanya untuk menjelaskan adanya gejala komodifikasinya. Dalam hal ini, data menyangkut ngibakan dan ngaras versi lama diambil berdasar wawancara dengan sejumlah informan yang kompeten mengetahui awal-mula dua tradisi tersebut. Sementara itu, versi pengembangan barunya, peneliti banyak mengambil data yang bersumber pada Mitra Seni Inten Dewangga di dalamnya terdapat beberapa aspek mengenai proses pelaksaanaan beserta bentuk ngibakan dan ngaras yang telah mengalami proses pengolahan lebih lanjut menjadi sesuatu yang baru sebagai gejala yang nantinya dianalisa dengan komodifikasi. 


\section{Upacara Ngaras}

Peneliti menguraikan urut-urutan yang terdapat dalam bentuk lama serta baru upacara ngaras kedalam enam rangkaian yang terdiri dari pengajian dan tausiah, ngecagkeun aisan, menyalakan pelita dan menyebutkan arti siloka dedaunan, sungkem, mencium dan mencuci kaki orang tua, serta meminta doa restu pada kerabat.

\section{a. Pengajian dan tausiah}

Upacara ngaras pada bentuk lama diawali dengan pengajian yang sengaja mengundang para ibu-ibu dan para tetangga yang dilakukan di dalam rumah. Di mana dalam pelaksanaanya membacakan kalam ilahi serta tausiah mengenai pernikahan. Dalam pelaksanaannya sebelum acara pengajian dimulai terlebih dahulu telah disusun peralatan yang akan digunakan dalam upacara ngaras seperti aneka dedaunan, paso (bejana tanah liat) berisi air kembang, kendi, kain batik sebanyak tujuh helai, parfum, sapu tangan, sumbu, dan ulekan tanah liat yang ditata sedemikian rupa di atas hamparan tikar pandan yang digelar di hadapan kursi yang nantinya akan dijadikan tempat duduk kedua orang tua calon pengantin.

Pada perkembangannya saat ini pengajian selain mengundang para ibu-ibu majelis taklim yang ada di sekitar tempat dilaksanakannya upacara ngaras, adapula beberapa pemangku hajat yang mengundang tempat pengajian khusus yang biasa di pakai baik dari tempat kerja atau majelis taklim lain meskipun biasanya jauh dari lokasi ngaras.

Selain itu, peralatan yang disusun untuk didoakan tidak disimpan pada tikar pandan namun disimpan pada kain putih berenda yang terdiri dari air tujuh sumur yang akan dipakai pada prosesi ngibakan digantikan oleh air dari tujuh merek yang berbeda hal ini dikarenakan air dari tujuh merek dianggap merupakan air yang bersumber dari tujuh mata air yang berbeda juga sehingga lebih mudah untuk digunakan seperti:

1) Merek Aqua merupakan air yang bersumber dari mata air Ciherang kabupaten Bogor dan dari mata air cipondok Pasanggrahan, Kasoma- lang, Kabupaten Subang, Jawa Barat.

2) Merk Ron 88 merupakan air yang bersumber dari mata air di pegunungan Mandalawangi, Kec. Nagreg, Bandung, Jawa Barat.

3) Merk Le Minerale merupakan air yang bersumber dari mata air di kampung Keramat, Kecamatan Cadasari Pandeglang dan dari Kampung Cipancur, Kecamatan Baros, Kabupaten Serang.

4) Merk Al-Masoem berasal dari mata air gunung Manglayang Jawa Barat.

5) Merk Club berasal dari mata air Pandaan, Gunung Arjuno, Pasuruan, Jawa Timur.

6) Merk Summit berasal dari mata air Tamansari, Bogor, Jawa Barat

7) Air zam-zam yang bersumber dari asalnya di bawah Hajar Aswad dan di bawah Gunung Abu Qubays dan Shafa, dan di bawah bukit Marwa.

Ketujuh air ini masing-masing dimasukan ke dalam mangkuk kristal kecil dan diberi taburan bunga melati kuncup dan bunga kenanga.

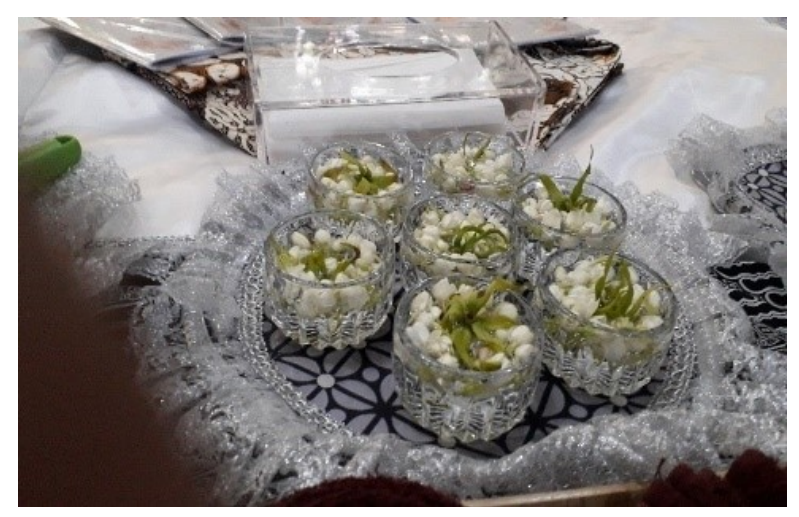

Gambar 1. Air tujuh Sumber didalam gelas kristal. (Foto: Dok. M.Irfan, 15 november 2019)

Selain ketujuh air tersebut disusun juga dua wadah yang lebih besar yang terbuat dari kristal serta diberi taburan bunga melati dan bunga kenanga serta beberapa bunga mawar dan diberi alas berenda agar terlihat lebih cantik, di mana salah satu wadah ini akan digunakan oleh calon pengantin pria dalam melaksanakan proses ngibakan. Semua air ini diletakan di tengah bertujuan agar ikut didoakan sehingga dianggap air ini akan mendapat ber- 
kah untuk dicampurkan ke dalam gentong dalam prosesi ngibakan

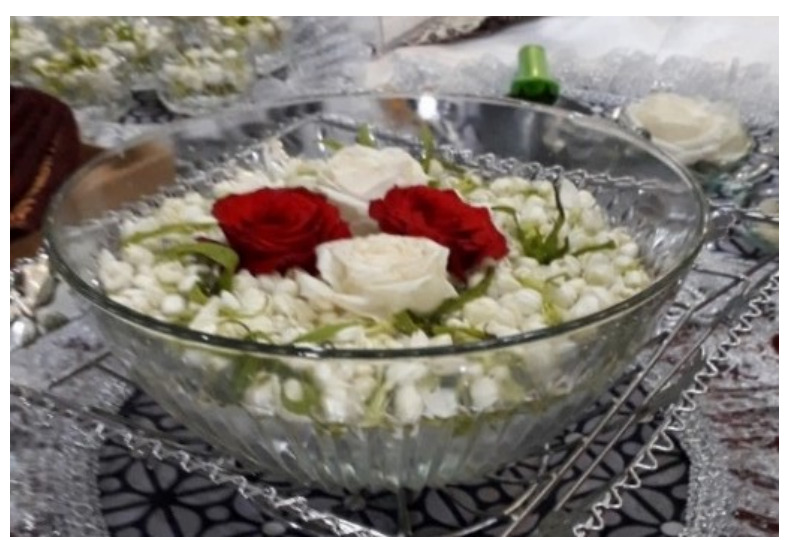

Gambar 2. Bokor tempat air Doa. (Foto: Dok. M. Irfan, 10 Januari 2020)

b. Ngecagkeun aisan atau melepaskan gendongan

Prosesi berikutnya adalah prosesi ngecagkeun aisan, baik dalam bentuk lama maupun pada versi baru pada MSID rangkaian prosesi ini tetap sama dimana ibu mengikatkan kain sinjang kepada calon pengantin seolah olah sedang menggendong dengan didampingi oleh sang ayah di depannya sambil membawa lilin atau damar cempor yang menyala dari mulai depan kamar menuju tempat ngaras sebagai tanda ibu yang selama ini mengasuh serta ayah yang selalu menjadi pelita di setiap perjalanan hidup anaknya yang akan melepaskan tanggung jawab keduanya setelah menikah nanti.

Perbedaan pada perkembangannya lilin yang digunakan menggunakan lilin bulat yang di simpan pada tempat kristal serta prosesi ini berjalan melewati hamparan kain sinjang yang telah disediakan.

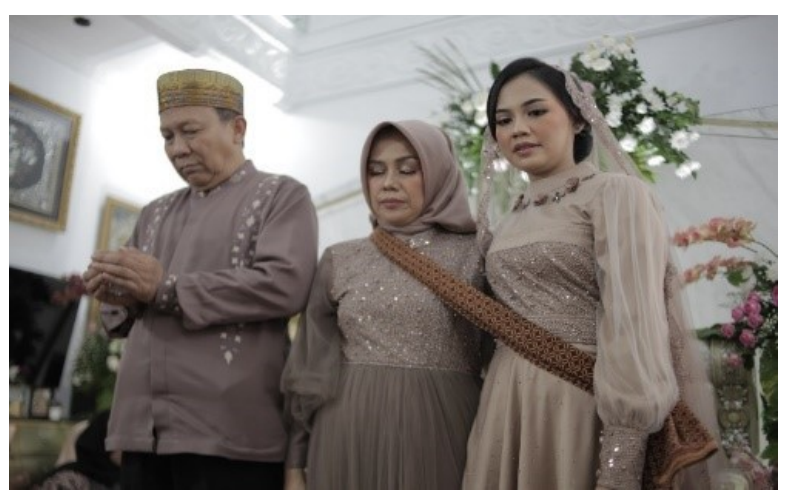

Gambar 3.Prosesi ngecagkeun aisan. (Foto:Dok. M. Irfan, 12 Maret 2020) c. Menyalakan pelita dan menjelaskan siloka dedaunan

Pemandu adat akan menjelaskan mengenai siloka atau filosofi makna dari daun yang telah disediakan dimana terdiri atas daun hanjuang, sirih, puring, melati, beringin, mamangkokan, kibeusi, waregu, serta handeuleum. Adapun arti dari dedaunan tersebut menurut Suryalaga (1998: 32) adalah sebagai berikut:

1) Hanjuang bermakna sepanjang kita diberi kesempatan untuk ngahanju (bernapas), kita diharuskan memiliki kahayang (cita-cita). Makna lainnya adalah sebagai batas antara masa lajang dengan masa berumahtangga.

2) Seureuh (sirih) dimaknai sebagai reureuh (berhenti) dalam mengumbar nafsu, karena dalam beberapa saat lagi sudah akan memiliki teman hidup. Makna lain adalah kasih sayang antara calon mempelai wanita dengan calon mempelai pria.

3) Puring dimaknai sebagai mpu kuring artinya sang guru (Mpu) yang bersemayam di badan kuring atau pada diri sendiri.

4) Melati dimaknai sebagai sekecil apapun kasih sayang yang diberikan harus dihargai seputih bersih seperti bunga melati.

5) Beringin dimaknai bahwa dalam mengarungi kehidupan harus mam$\mathrm{pu}$ berperan sebagai pengayom, atau siap melindungi oranglain.

6) Mamangkokan dimaknai sebagai sikap tumarima (berterima) akan rezeki yang diberikan oleh Tuhan, baik dalam jumlah yang besar maupun dalam jumlah yang kecil. Daun mamangkokan baik yang besar maupun yang kecil, bentuknya seperti mangkuk; seperti tangan yang sedang menengadah memanjatkan rasa syukur.

7) Kibeusi dimaknai sebagai kekuatan yang keras; bahwa hidup senantiasa menghadapi persoalan.Sementara kita harus tetap sigap dalam menghadapi setiap persoalan. 
8) Waregu dimaknai sebagai waruga (badan, fisik) yang harus senantiasa weweg (kuat) dalam menghadapi rintangan.

9) Handeuleum dimaknai sebagai alam ide, angan-angan, atau citacita. Dalam bahasa Sunda ada ungkapan "teundeun di handeuleum hieum, tunda di hanjuang siang."'Handeuleum hieum', berarti alamide.

Setelah menguraikan arti yang terkadung di dalam aneka dedaunan, dilanjutkan pada prosesi berikutnya di mana calon pengantin dipersilakan untuk menyalakan pelita, yang terdiri atas lima sumbu pelita yang disusun di dalam coet tanah liat (cobek) hal ini dimaksudkan agar pada saatnya nanti berumah tangga, sang mempelai harus tetap mampu menyalakan lima unsur dalam rumah tangga yaitu Islam, iman, shiddiqiyyah (kejujuran), sa'adah (kebahagiaan), dan muraqabah (mawas diri). Adapun pelita tersebut ditempatkan di dalam coet tanah liat, sebagai pengingat bahwa semua manusia terbuat dari tanah dan akan kembali ke tanah.

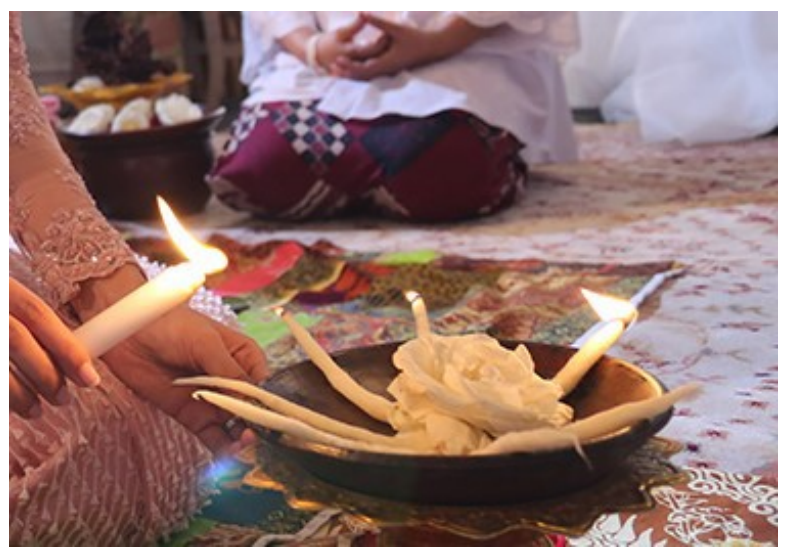

Gambar 4. Menyalakan Sumbu di atas Coet. (Foto: Dok. The Bride, 12 Mei 2013)

Dalam perkembangannya pada Mitra Seni Inten Dewangga tidak terdapat prosesi siloka daun dan penyalaan pelita dikarenakan daun yang sulit untuk didapatkan serta dikhawatirkan penyalaan sumbu ini dapat mengakibatkan hal-hal yang tidak diinginkan (kebakaran). d. Sungkem atau permintaan maaf dan izin kepada orang tua

Dalam prosesi ini calon pengantin bersimpuh menghadap kepada kedua orang tua calon tersebut di atas tujuh kain batik yang telah dilipat dan disusun rapi di atas hamparan tikar pandan. Kain yang digunakan ini dilambangkan sebagai perjalanan hidup yang senantiasa berada dalam lingkaran tujuh hari, di mana setiap insan wajib menghargai waktu.

Sesuai dengan yang terkandung pada Al Qur'an surat Al Ashr yang menyebutkan, "Demi waktu, sesungguhnya manusia itu berada dalam kerugian, kecuali mereka yang senantiasa saling mengingatkan dalam kebenaran serta dalam kesabaran." Sehingga dalam mengisi waktu yang tujuh hari dalam seminggu, kita senantiasa diingatkan untuk selalu berbuat baik.

Sungkem diawali dengan permintaan maaf serta permohonan izin oleh calon pengantin kepada orang tua, yang kemudian izin serta pesan akan dibalas oleh ayah dilanjutkan dengan meminta maaf dan ijin kepada kakek dan nenek serta saudara kandung yang secara langsung disampaikan oleh calon pengantin.

Dalam perkembangannya tujuh kain sinjang yang dijadikan tempat duduk calon pengantin dibentuk sesuai dengan kreasi, memiliki perbedaan pengertian namun memiliki nilai pesan yang sama agar lebih universal, menurut bapak Deny Mulyadi kain sinjang ini dimaknai sebagai pengingat bahwa ada tiga kehidupan manusia yang menggunakan kain tersebut yaitu yang pertama saat dilahirkan ke alam dunia masyarakat Sunda biasanya menggunakan kain sinjang untuk menyelimuti bayi atau dikenal dengan istilah dibedong, yang kedua saat pernikahan nanti di mana akan menggunakan kain sinjang, dan yang ketiga adalah di saat meninggal dunia yang akan di harudung atau ditutup juga oleh kain sinjang ${ }^{1}$.

Pada proses permintaan maaf serta permohonan izin kepada orang tua, kakek

\footnotetext{
${ }^{1}$ Hasil Wawancara kepada Bapak Deny Mulyadi tanggal 24 Maret 2020.
} 
dan nenek serta saudara kandung pada saat ini biasanya pemangku hajat meminta untuk dibuatkan isi kata-katanya oleh MSID.

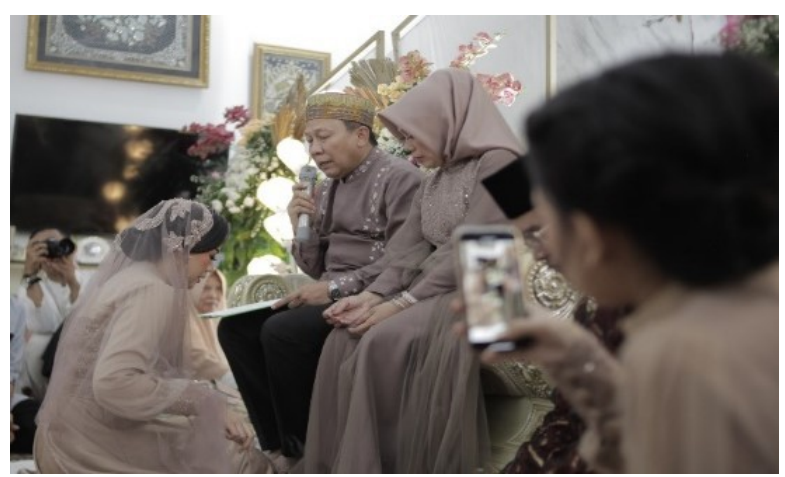

Gambar 5. Prosesi sungkem dan Izin kepada Orang tua. (Foto: Dok. M. Irfan, 12 Maret 2020)

\section{e. Mencuci dan mencium kaki kedua orang tua}

Sebelum calon pengantin mencuci kaki, kedua orang tua mengucurkan air yang berada di dalam kendi untuk dituangkan ke dalam paso yang terbuat dari tanah liat yang berisi aneka bunga. Pada saat menuangkan air, baik kedua orang tua maupun calon mempelai, dipersilakan untuk membacakan doa keselamatan di dalam hati masing-masing.

Prosesi ini dilambangkan sebagai kasih sayang yang dicurahkan oleh kedua orang tua kepada anaknya. Setelah air dari dalam kendi itu habis, maka air yang sudah berada di dalam paso selanjutnya dipergunakan untuk membasuh kaki kedua orang tua dengan air kembang dari paso dengan penuh hormat oleh sang calon mempelai. Sambil membasuh kaki, sang calon mempelai dihantar oleh pemandu adat untuk membacakan doa keselamatan bagi kedua orang tua. Jika kaki kedua orang tua telah selesai dibasuh, maka sang calon mempelai selanjutnya melapnya dengan sapu tangan hingga kering, Setelah itu disemprot wewangian dari parfum. Terakhir, sambil bersimpuh di kaki kedua orang tuanya serta mencium kedua kaki orang tuanya seraya membacakan doa.

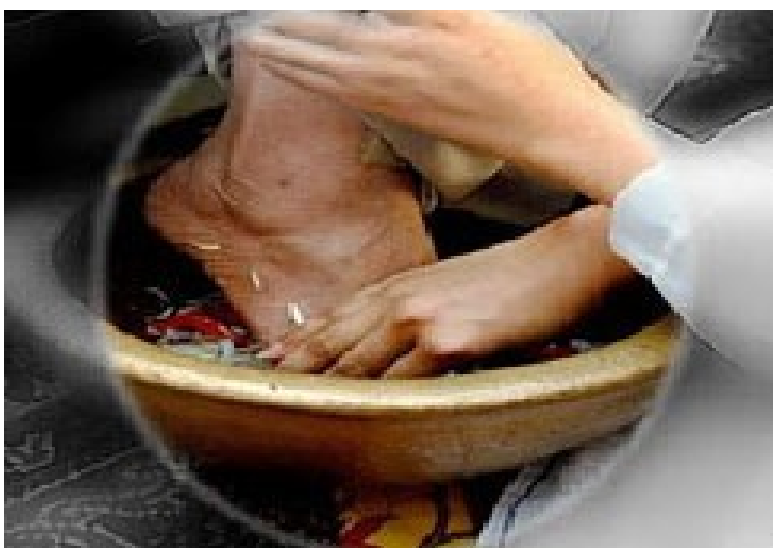

Gambar 6. Mencuci kaki orang Tua di dalam paso. (Foto: Dok. Riska, 2010)

Pada perkembangannya kemudian, peralatan yang digunakan untuk mengucurkan air tebuat dari bahan kaca yang dikucurkan ke dalam sebuah bejana yang terbuat dari kristal yang berisi melati. Proses ini dilanjutkan oleh ibu yang akan menaburkan bunga mawar berwarna putih sebagai lambang kesucian dan ayah akan menaburkan bunga mawar berwarna merah sebagai lambang jajaten atau keberanian ke dalam air tersebut.

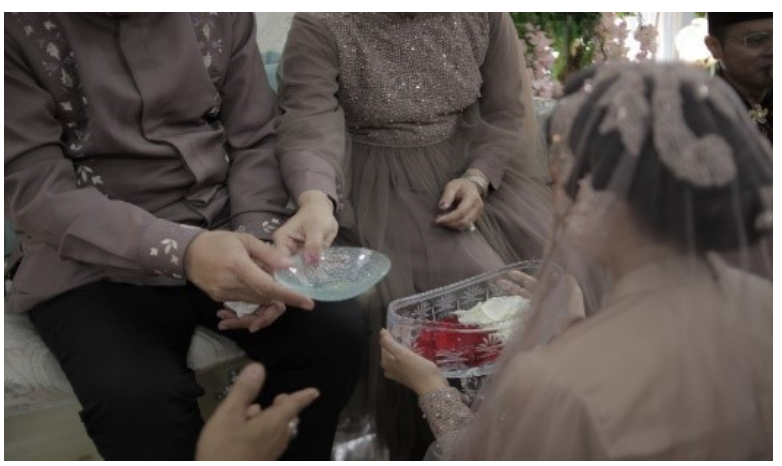

Gambar 7. Prosesi menaburkan bunga kedalam air ngaras.

(Foto: Dok. M. Irfan, 12 Maret 2020)

Berbeda dengan versi lama dimana kaki dimasukan ke dalam paso pada pengembangan ini kaki kedua orang tua hanya diseka dengan mencelupkan kain handuk kecil kemudian dikeringkan. Setelah itu di semprot wewangian dari parfum dan mencium kaki kedua orang tuanya seraya membacakan doa. 


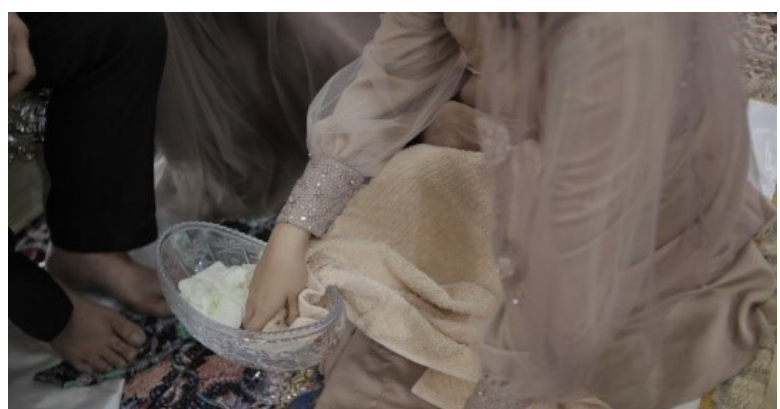

Gambar 8. Prosesi Mencuci Kaki orang tua. (Foto: Dok. M.Irfan, 12 Maret 2020)

\section{f. Meminum air zam-zam}

Prosesi ini adalah prosesi meminum kan air zamzam yang merupakan kreativitas yang ditambahkan pada MSID, air zam- zam sudah disediakan pada gelas kecil di minumkan oleh orang tua yang diawali oleh ibu kemudian ayah kepada calon pengantin dan sebaliknya dari calon pengantin kepada ibu dan ayah, dilanjutkan dengan orang tua meminumkan kepada adik atau kakak dari calon mempelai sebagai perlambang keberkahan dan diharapkan sekeluarga dapat pergi ke tanah suci dan meminum air zam-zam secara langsung di sana.

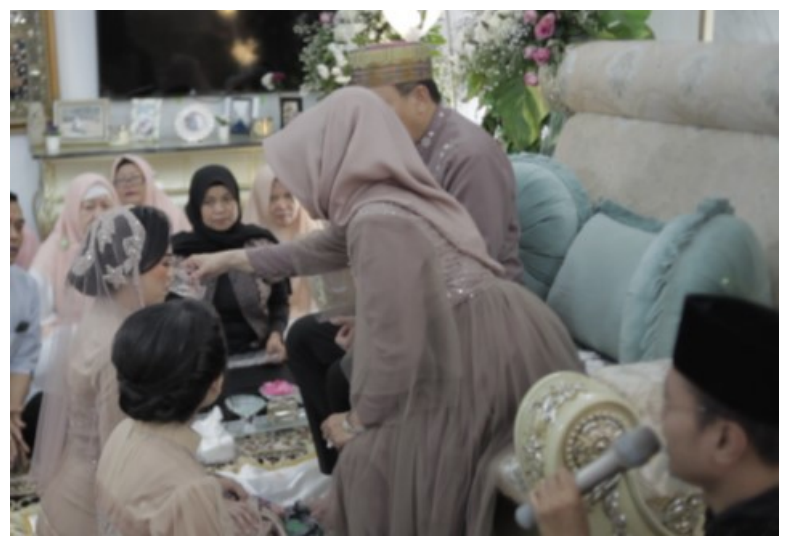

Gambar 9. Meminumkan air zam-zam. (Foto: Dok. M. Irfan, 12 Maret 2020)

g. Meminta doa restu kepada kerabat

Baik bentuk lama maupun baru upacara ngaras diakhiri dengan meminta doa restu dengan bersalaman kepada para kerabat dan hadirin yang hadir, kemudian pengantin akan menuju ke tempat ngibakan bersama orang tua. Namun pada perkembangannya calon pengantin akan berganti pakaian terlebih dahulu, dan dipasangkan melati dada sepinggang serta bondu melati, setelah itu pengantin dan orang tua akan berjalan mengikuti hamparan kain sinjang yang sudah digelar. Kain sinjang terdiri atas warna berbeda dan sudah dijahit, hal ini dimaksudkan untuk mempermudah pemakaiannya tanpa harus menyusunnya satu persatu. Adapun faktor lain, dikarenakan jarak antara kamar dan tempat ngibakan yang biasanya jauh sehingga tidak akan sampai jika hanya menggunakan tujuh kain sinjang saja.

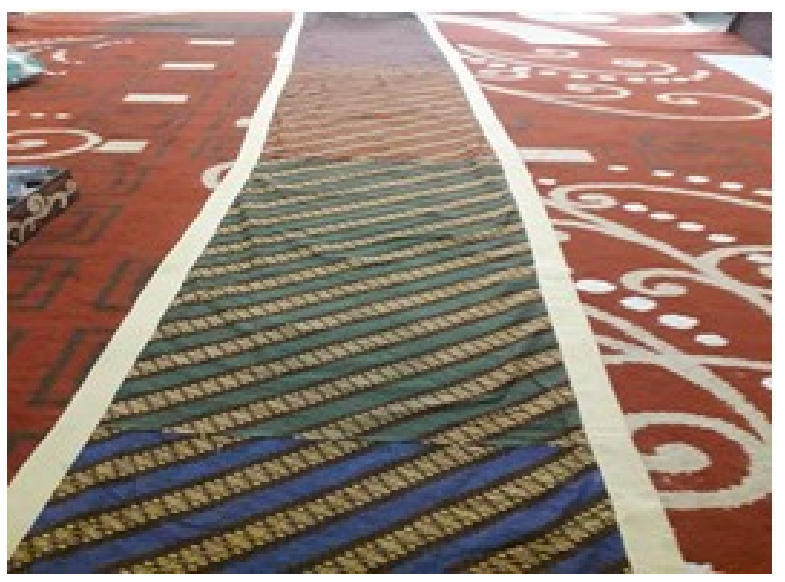

Gambar 10. Kain sinjang yang sudah dijahit. (Foto: Dok. M. Irfan, 12 Maret 2020)

h. Serah terima air doa untuk siraman

Setelah ngaras dilaksanakan selanjutnya merupakan penyerahan air yang terdapat pada dua wadah besar yang akan dipakai prosesi ngibakan dari pimpinan tausiah kepada orang tua, selanjutnya penyerahan salah satu wadah dari orang tua kepada perwakilan keluarga pria yang kemudian didokumentasikan. Prosesi ini juga merupakan bentuk baru yang sebelumnya tidak ada.

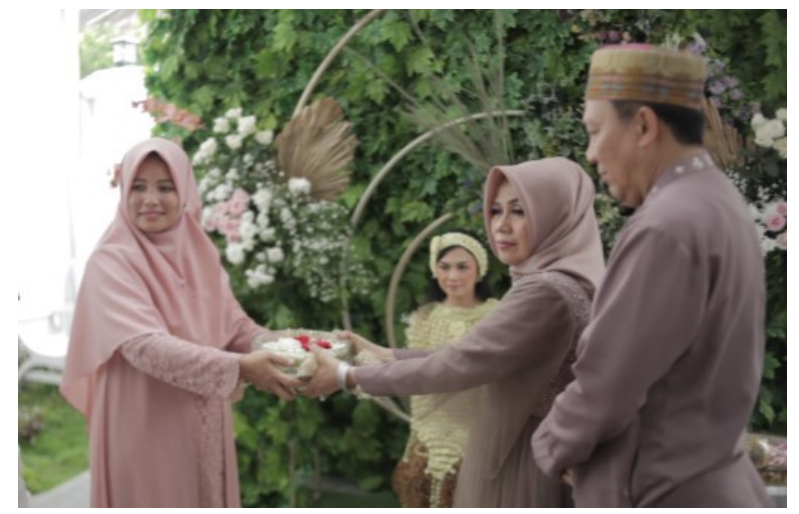

Gambar 11. Penyerahan air doa dari pimpinan pengajian.

(Foto: Dok. M. Irfan, 12 Maret 2020) 


\section{Bentuk dan Rangkaian Upacara Ngibakan}

Pada prosesi ngibakan peneliti akan menguraikan bentuk lama maupun baru yang terdiri dari mencampur air tujuh sumber/sumur, ngibakan. Potong rambut dan ngeningan, rebutan parawanten, pemotongan tumpeng dan mengubur rambut.

Pelaksanaan Ngibakan bentuk lama diawali dengan orang tua menuju ke sebuah bale (saung) yang berada di halaman luar yang akan dijadikan tempat dilaksanakannya upacara ngibakan. Bale ini dibuat secara gotong royong oleh keluarga dari calon pengantin termasuk dalam pembuatan janur yang digunakan sebagai dekorasinya, di tempat tersebut sudah disediakan peralatan berupa gentong tanah liat, siwur batok atau gayung dari batok kelapa, tujuh kendi yang berisi air dari tujuh sumur atau tujuh mata air, ulekan tanah liat, gunting, parawanten, dan kain putih.

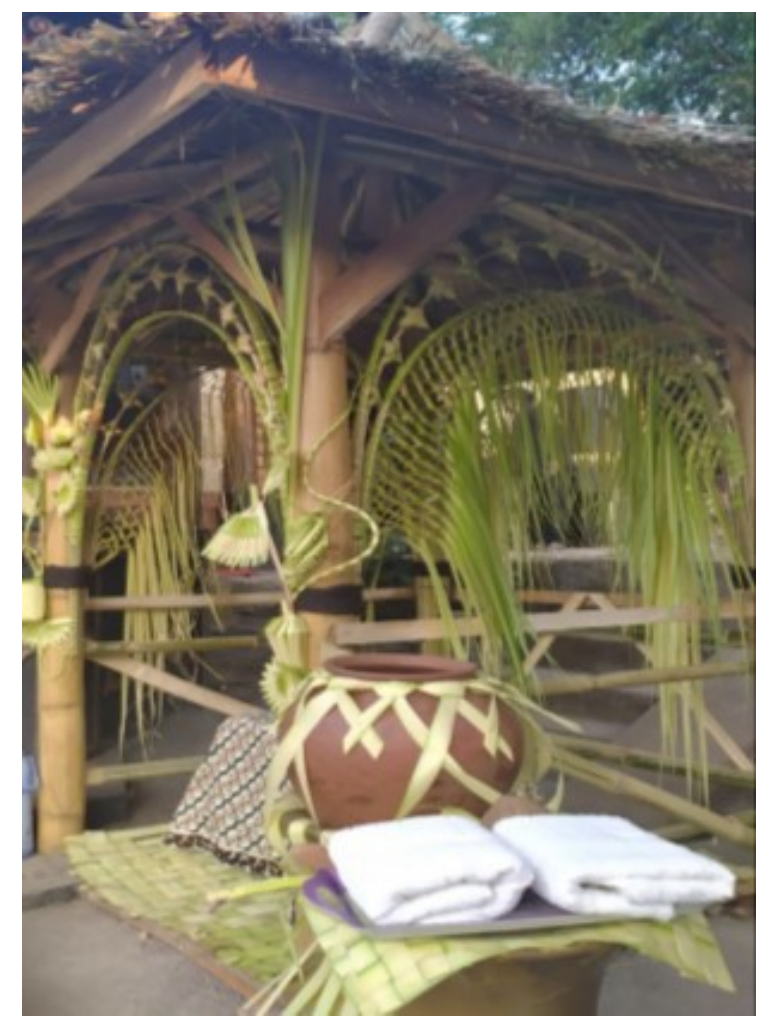

Gambar 12.Bale tempat pelaksanakan upacara Ngibakan.

(Foto: Dok. M. Irfan, 22 Juni 2019)

Sedangkan dalam bentuk baru tidak lagi menggunakan bale tetapi merupakan dekorasi yang sudah dipesan kepada penyedia jasa

\section{Mencampur air tujuh sumur}

Prosesi diawali dengan mencampurkan air tujuh sumur dari kendi ke dalam gentong yang berisi bunga setaman oleh kedua orang tua yang kemudian mengaduk-aduknya.

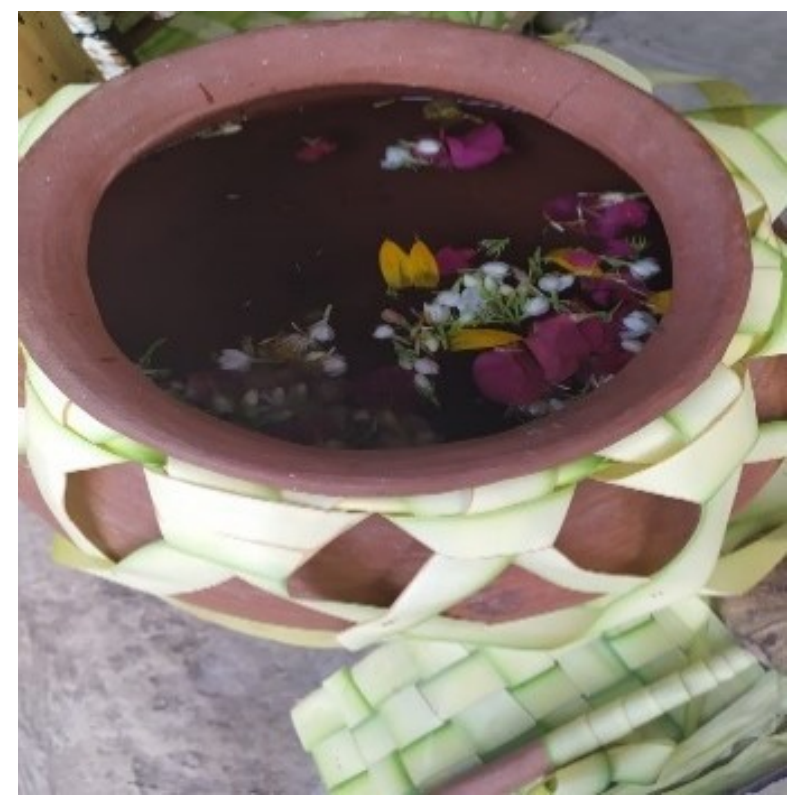

Gambar 13. Gentong tanah liat berisi air untuk Ngibakan.

(Foto: Dok. M. Irfan, 2019)

Pada perkembangannya, prosesi sama dengan bentuk lama yaitu dengan mencampur air namun dari wadah kristal kemudian air dari tujuh sumber ke dalam gentong kuningan yang berisi bunga setaman, melati, dan beberapa bunga mawar utuh oleh kedua orang tua untuk diaduk-aduk.

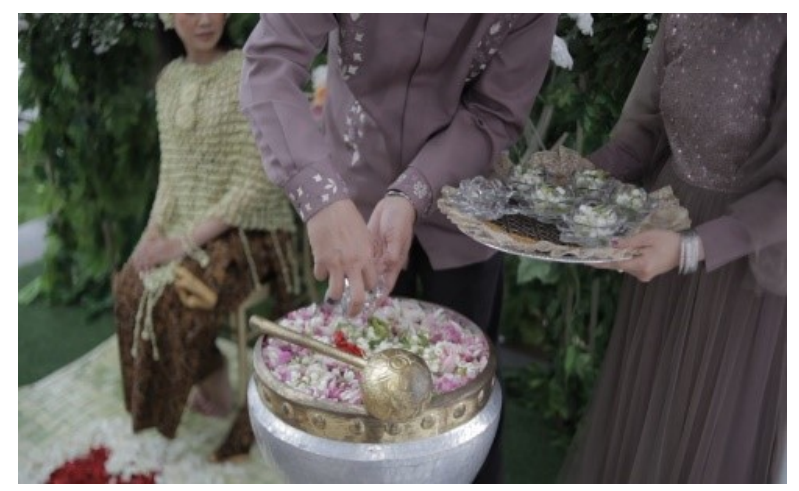

Gambar 14. Prosesi pencampuran air tujuh sumber.

(Foto: Dokumen M.Irfan, 12 Maret 2020)

\section{Ngibakan atau memandikan calon pengantin}

Proses ngibakan ini diawali oleh calon pengantin yang berjalan menuju tempat dilak- 
sanakannya upacara ngibakan dengan menginjak tujuh kain sinjang yang telah disusun menuju tempat ngibakan, proses ngibakan ini diawali oleh ibu menyiramkan air yang terdapat dalam gentong kepada calon pengantin sebanyak tiga kali atau tiga siwur yang dilanjutkan kemudian oleh ayah sebanyak tiga kali, di mana siraman pertama dilakukan pada ubun-ubun, siraman kedua dilakukan pada pundak kanan dan kiri, siraman ketiga dilakukan pada badan hingga kaki dari calon pengantin sambil membacakan doa di dalam hati agar dalam pelaksanaan pernikahan nantinya calon pengantin diberikan kelancaran.

Ngibakan dilanjutkan oleh orang yang dituakan oleh calon pengantin atau disebut sepuh dan pinisepuh seperti kakek, nenek, paman atau uwa dari calon pengantin yang berjumlah ganjil yaitu, tujuh, sembilan, atau paling banyak sebelas orang.

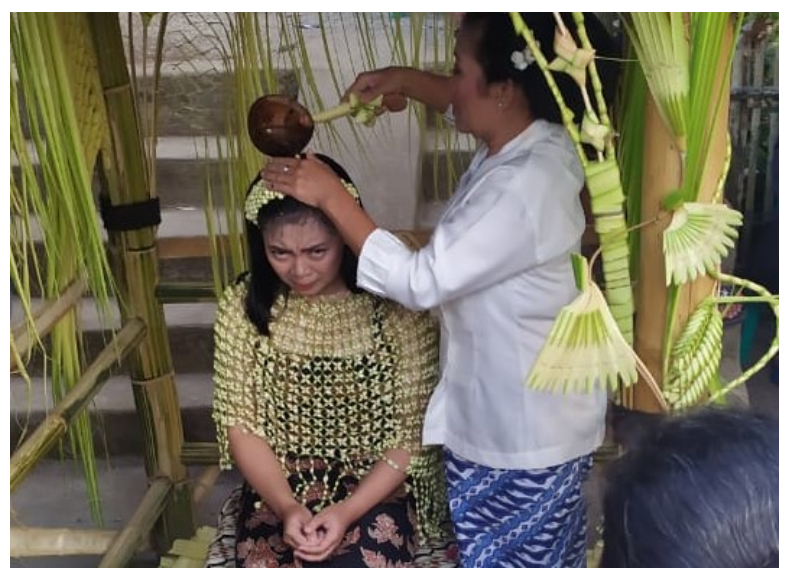

Gambar 15.Proses ngibakan oleh Ibu. (Foto: Dok. M. Irfan, 22 Juni 2019)

Prosesi ngibakan ini memiliki kesamaan dengan bentuk lama namun sebelum mendatangkan orang tua dan calon pengantin gentong akan diisi terlebih dahulu oleh air hangat agar nantinya calon pengantin tidak merasa kedinginan. Namun setelah prosesi penyiraman oleh para sesepuh atau orang yang dituakan ini akan memperoleh bingkisan yang berupa peralatan bersih-bersih diri yang terdiri atas cermin, sabun, sampo, sisir, serta handuk yang biasanya dipesan kepada MSID sebagai tanda terima kasih dari orang tua pihak calon pengantin kepada keluarga yang telah ikut menyiram dan mendoakan calon pengantin.

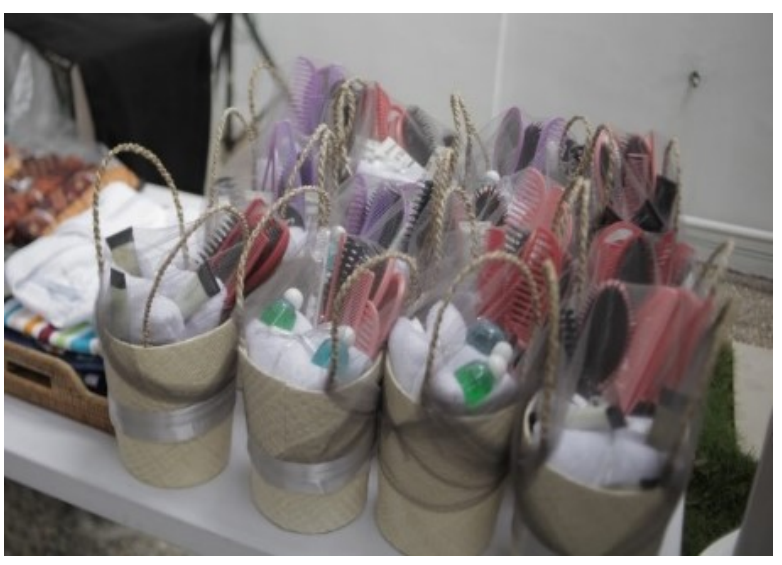

Gambar 16. Souvenir untuk yang memandikan. (Foto: Dok. M.Irfan, 12 Maret 2020)

\section{Berwudhu}

Pada pengembangan terdapat prosesi berwudhu bagi yang beragama islam setelah prosesi ngibakan, agar lebih sempurna air wudu bersumber dari kendi yang dikucurkan oleh kedua orang tua.

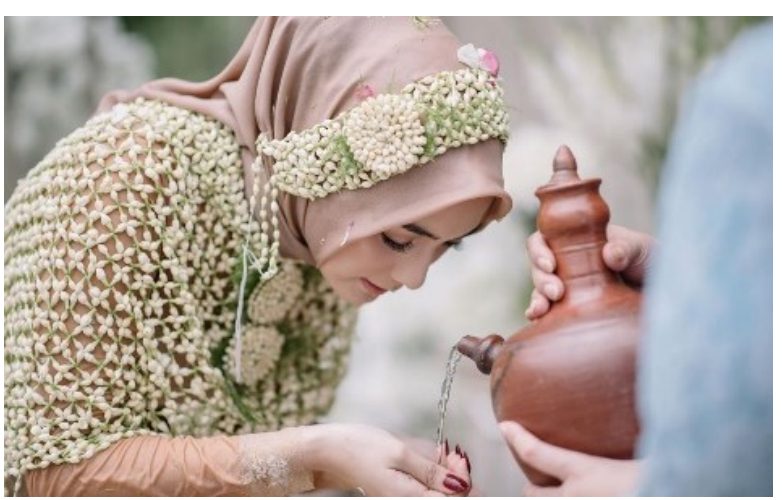

Gambar 17. Prosesi berwudhu.

(Foto: Dok. Imagenic 26November 2019)

\section{Potong rambutdan ngeningan}

Calon pengantin dipotong rambutnya sedikit oleh kedua orang tua sebagai lambang untuk memperindah diri baik secara lahir dan batin. Potongan rambut ini kemudian disimpan di dalam ulekan tanah liat untuk nantinya dikubur di pekarangan rumah dalam proses selanjutnya setelah itu calon pengantin juga akan dicukur bulu-bulu halus pada wajah, kuduk, membentuk amis cau/sinom, membuat godek serta kembang turi.

Sedangkan dalam perkembangannya tidak ada ngeningan hanya memotong sedikit rambut oleh kedua potongan rambut ini kemudian disimpan di dalam sausser atau piring kecil untuk nantinya dikubur di pekarangan rumah. kemudian orang tua mengeringkan calon pengantin dengan handuk oleh ibu dan 
memasangkan handuk kimono oleh ayah dan kemudian berganti baju.

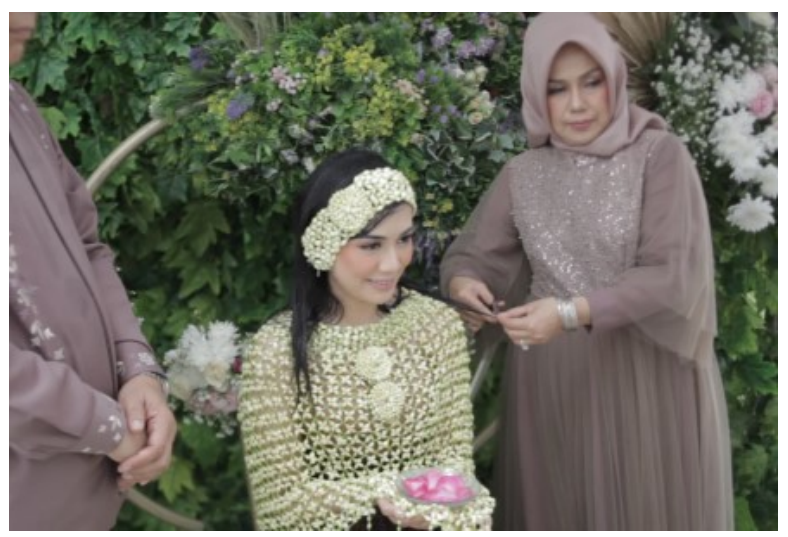

Gambar 18. Prosesi Memotong Rambut. (Foto: Dok. M. Irfan, 12 Maret 2020)

\section{Rebutan parawanten (sesaji)}

Sembari menunggu calon pengantin dirias, pada prosesi bentuk lama terdapat rangkaian rebutan parawanten (sasaji) yang tidak terdapat dalam versi baru, parawanten ini telah disediakan oleh keluarga di mana para tamu diperbolehkan untuk mengambil parawanten ini setelah dibuka, yang terdiri atas:

nyiru (satu buah tampah besar), boboko (bakul), cukil (sendok nasi), hihid (kipas dari bambu), coet (cobek tanah liat), mutu, aseupan (kukusan berbentuk kerucut), kacip (alat pembelah pinang), beras semangkuk, lemareun atau bahan-bahan untuk menyirih, rujakeun (buahbuahan untuk membuat rujak), hahampangan (kue kering seperti opak, kolontong, borondong dan lain-lain), jajanan pasar seperti kue basah seperti nagasari, bugis, apem dan lainlain), bubur merah putih, congcot puncak manik (nasi yang diambil dari puncak $k u k u$ san), di atasnya disimpan telur rebus dengan kulitnya, pisang emas satu sisir, pisang raja satu sisi, samara badag (bumbu-bumbu seperti seperti lengkuas, salam dan sebagainya), bumbu dapur (garam gandu, gula gandu, kelapa muda satu butir, kelapa tua satu butir, daun pisang satu kompet atau satu ikat, kayu bakar tiga potong, rampe atau bunga sebungkus, rokok dan korek api, benang putih dan hitam, jarum, kemenyan putih, dupa, bedak, sisir, cermin, minyak kenanga, minyak wangi, tujuh macam buah, macam-macam umbi, gula, kopi, semuanya ditutup oleh kain warna putih.

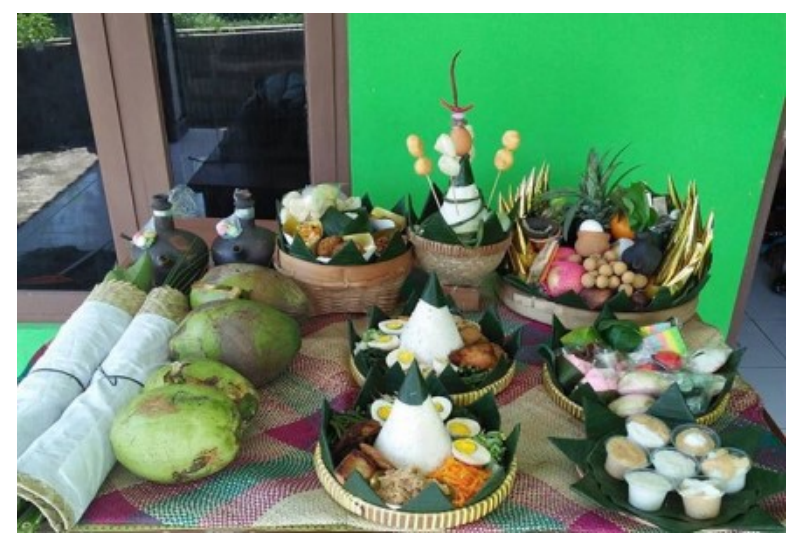

Gambar 19. Parawanten.

(Foto: Dok. Guntur, 7 Februari 2019)

Prosesi tersebut merupakan simbol agar calon pengantin mendapat kelancaran rezeki dengan berbagi, cepat mendapat keturunan, dan selalu mendapatkan kemudahan dalam menghadapi masalah rumah-tangga. Selain itu, para tamu juga diperbolehkan untuk mengambil air siraman yang dipercaya dapat menjadi doa agar lancar jodoh.

\section{Sawer sinjang dan saweruang}

Sebagai pengganti dari rebutan parawanten yang terdiri aneka macam maka ditambahkan prosesi sawer kain sinjang yang akan disawerkan atau dilempar oleh keluarga di mana para tamu nantinya akan saling berebut untuk mendapatkannya. Selain sawer sinjang terkadang keluarga juga akan melemparkan beberapa hadiah lain seperti mukena, sajadah, uang, serta permen yang dimaknai agar calon pengantin mendapat kelancaran rezeki dengan berbagi. Selain itu, para tamu juga diperbolehkan untuk mengambil air siraman yang dipercaya dapat menjadi doa agar lancar jodoh.

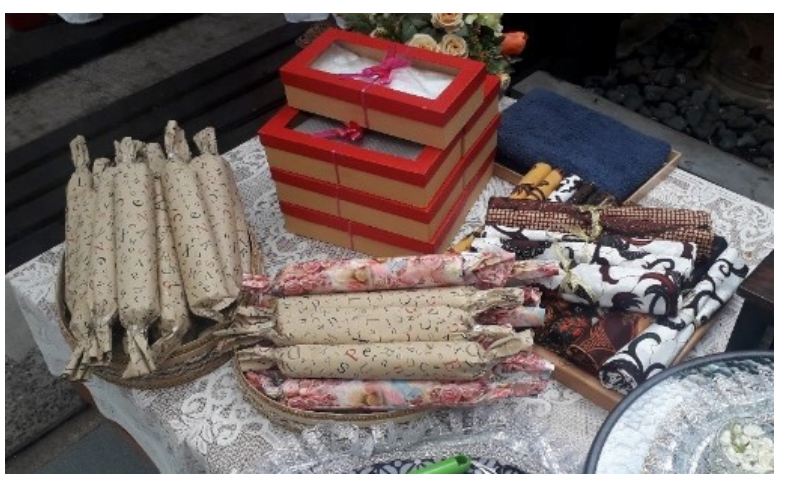

Gambar 20. Kain sinjang dan hadiah yang akan dijadikan sawer

(Foto: Dok. M. Irfan, 11 Maret2020) 


\section{Pemotongan tumpeng}

Pada bentuk lama setelah calon pengantin dirias dilanjutkan dengan pemotongan tumpeng oleh kedua orang tua serta pemberian suapan kepada calon pengantin sebanyak tiga kali sebagai simbol pelepasan orang tua kepada calon mempelai untuk hidup mandiri dengan keluarga baru kelak setelah menikah. Prosesi ini tidak terdapat pada versi baru.

\section{Mengubur rambut}

Kedua orang tua akan menanam potongan rambut calon mempelai wanita di tempat yang telah ditentukan di halaman rumah, penanaman rambut ini bermakna sebagai membuang atau menguburkan masa lalu calon mempelai yang dirasa kurang baik.

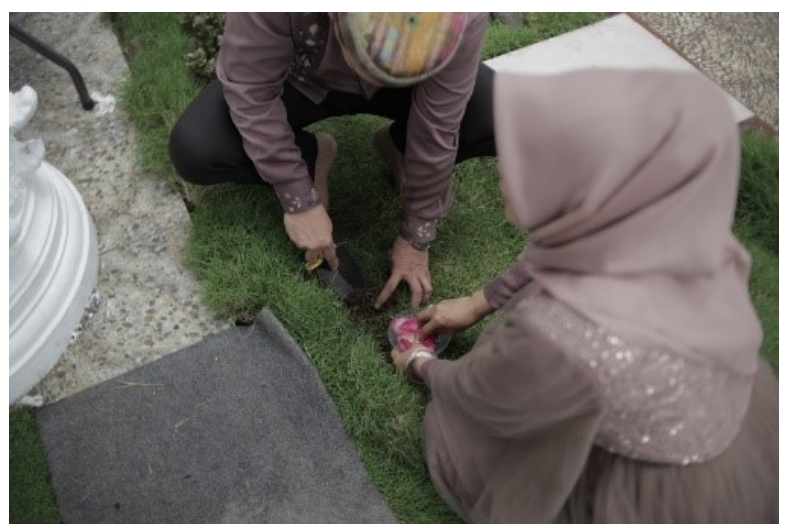

Gambar 21. Prosesi mengubur rambut di halaman Rumah.

(Foto: Dok. M. Irfan, 12 Maret 2020)

\section{Dekorasi Lama Upacara Ngaras dan Ngibakan}

Dekorasi upacara ngaras dan ngibakan pada zaman dahulu tidak seperti pada zaman sekarang, terutama pada upacara ngibakan disebabkan upacara ini lebih dulu ada sebelum ngaras dekorasi berupa anyaman janur yang dibuat sedemikian rupa yang merupakan adopsi dari kebudayaan Jawa dan priyayi Sunda, di mana seluruh prosesnya dilakukan oleh keluarga. Sedangkan dalam ngaras ini lebih berkembang namun tetap sederhana.

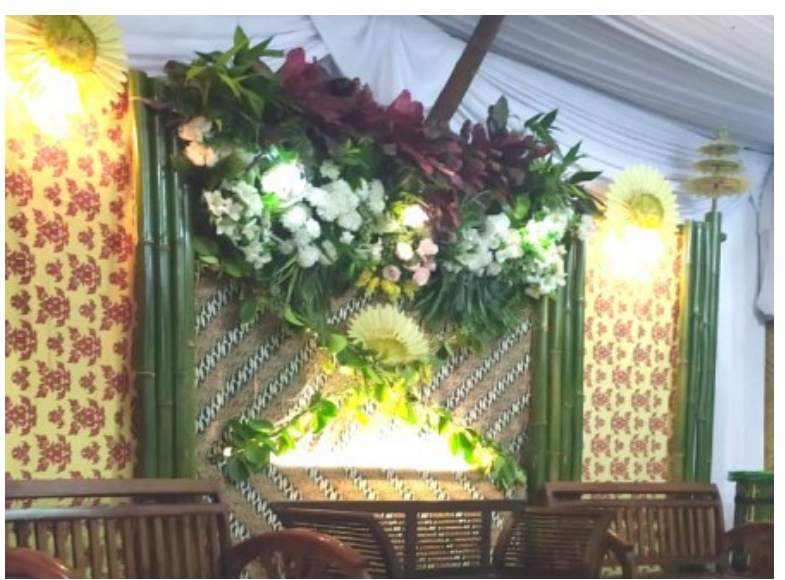

Gambar 22. Dekorasi Lama Upacara Ngaras (Foto: Dok. M. Irfan, 22 Juni 2019)

Berbeda dengan dekorasi pada Mitra seni Inten Dewangga mengikuti perkembangan bergaya modern minimalis yang sebagian besar menggunakan bunga asli terdiri dari bunga mawar berbagai warna, lili serta bunga dekorasi lainnya yang disesuaikan dengan permintaan pemangku hajat.

Bapak Ende mengatakan bahwa dekorasi ini bukan hanya terdapat pada upacara ngaras saja namun dekorasi terdapat pada tempat upacara ngibakan sehingga terdapat dua spot dekorasi yang berbeda yang memberikan kesan indah serta mewah bagi penggunanya. Harga dekorasi untuk upacara ngaras dan ngibakan ini berkisar pada harga Rp.4.000.000,- hingga yang paling mewah Rp. 10.000.000,- sesuai permintaan dari pemangku hajat ${ }^{2}$.

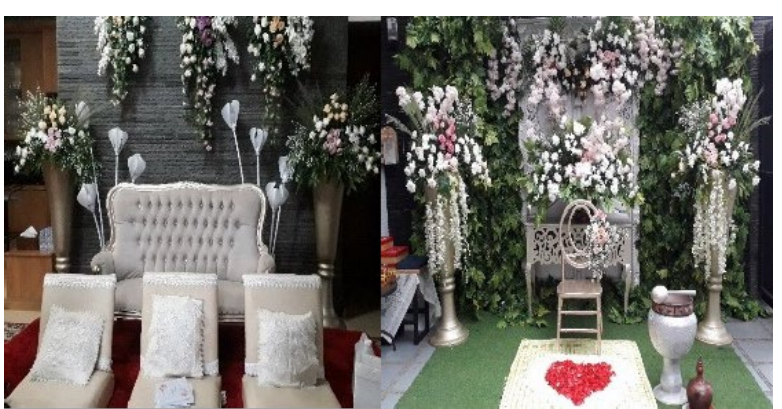

Gambar 23. Salah satu model Dekorasi Ngarasdan Ngibakan MSID.

(Foto: Dok. M. Irfan, 11 Maret 2020)
2 Wawancara dengan Bapak Ende (pemilik Dekorasi Khatulistiwa Bandung) pada 16 Februari 2020. 


\section{E. Pengguna Jasa Ngaras dan Ngibakan pada MSID di Kota Bandung}

Pengguna jasa Mitra Seni Inten Dewangga terdapat di beberapa kecamatan di Kota Bandung namun untuk mempermudah peneliti dalam menganalisis masyarakat yang menggunakan jasa tersebut, peneliti mengelompokkan ke dalam enam kecamatan yang paling sering menggunakan jasa ngaras dan ngibakan ini yang merupakan data yang diperoleh peneliti dari MSID sejak 18 Januari 2019 hingga 6 Maret 2020 yang diambil dari 70 pemangku hajat.

Dari 30 sampel yang diambil terdapat empat pekerjaan yang dominan di antaranya terdiri dari sebelas pemangku hajat yang memiliki pekerjaan sebagai pengusaha atau wirausaha, sembilan orang memiliki pekerjaan sebagai TNI, enam orang memiliki pekerjaan sebagai Polisi dan dua orang sebagai pegawai BUMN/PNS.

Selain pekerjaan hunian para pemang$\mathrm{ku}$ hajat ini juga dapat diklasifikasikan ke dalam masyarakat kelas menengah ke atas yang bertempat tinggal di beberapa komplek elit di Kota Bandung.

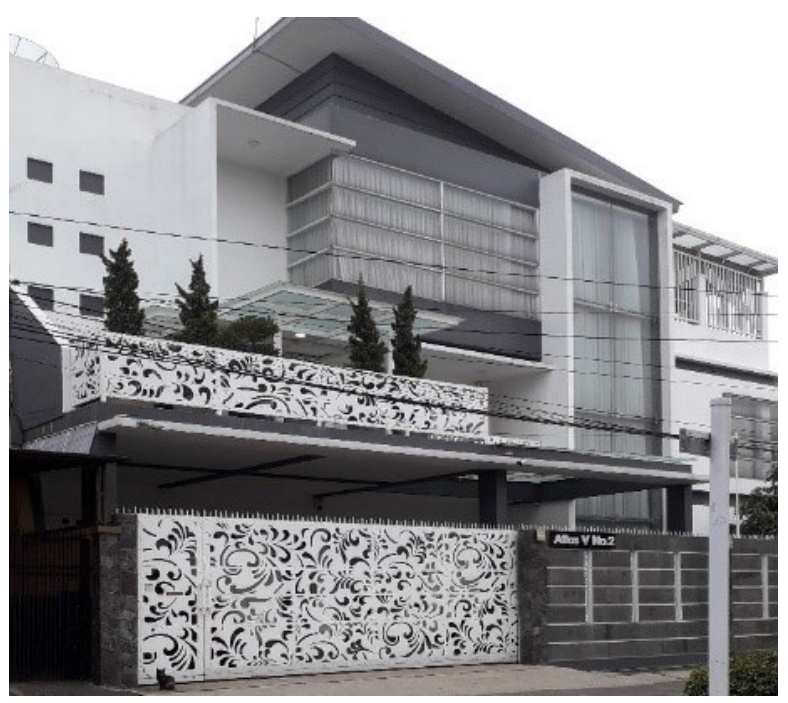

Gambar 24. Hunian Salah satu pemangku Hajat. (Foto: Dok. M. Irfan, 08 Maret 2020)

Menurut Bapak Iwa Permana S.Sen selaku pemilik Mitra Seni Inten Dewangga terdapat peningkatan jumlah pemangku hajat hingga $150 \%$ setelah adanya pengembangan modifikasi bentuk dan rangkaian pada upacara ngaras dan ngibakan ini dari mulai sejak tahun
2015. ${ }^{3}$ Hal ini diperkuat dari data pemangku hajat dimana adanya peningkatan jumlah pengguna jasa upacara ngaras dan ngibakan pada MSID dari 27 klien sebelum adanya modifikasi pada Januari 2012 - Maret 2013 menjadi 70 klien pada Januari 2019-Maret 2020 setelah adanya modifikasi.

\section{F. Perubahan Masyarakat}

Dari potensi-potensi yang mengakibatkan dampak arus globalisasi mudah masuk pada masyarakat Kota Bandung terjadi perubahan masyarakat yang awalnya merupakan masyarakat tradisional menjadi masyarakat modern. Hal ini berdampak pada pelaksanaan upacara ngaras dan ngibakan di mana masyarakat Kota Bandung yang masih melaksanakan upacara ini menyerahkan tanggung jawab pelaksanaan kepada penyedia jasa namun dengan pengemasan yang berbeda.

Hal ini membuat Mitra Seni Inten Dewangga dan masyarakat akan terus mencari informasi- informasi mengenai hal-hal yang baru dalam prosesi upacara ngaras dan ngibakan ini sebagai bagian dari penyebaran informasi yang sedang populer pada masa sekarang ini sehingga dapat menghasilkan nilai tukar maksimal. Upaya-upaya ini dilakukan, agar masyarakat terus menggunakan jasa MSID dalam melaksanakan ritual upacara ngaras dan ngibakan; di sisi lain, masyarakat selalu menginginkan hal-hal baru yang didapatkannya dari berbagai media. Dalam hal ini, dapat terlihat rasa gotongroyong yang dulu dilakukan oleh saudara serta keluarga mulai memudar karena tanggung jawab pelaksanaan diserahkan pada pemilik jasa.

Dalam acara pengajian pada ngaras saat ini terkadang pemangku hajat mengundang majelis taklim yang berada di luar tempat tinggalnya tersebut yang dikatakan biasa digunakan oleh pemangku hajat. Pemangku hajat juga biasanya mengundang ibu-ibu dari tempat bekerja seperti ibu Persit (Persatuan Istri Tentara Angkatan Darat Kartika Chandra Kirana) dan Bhayangkara (Perkumpulan istri Polri) serta tetangga yang dikenal. Dalam hal ini perubahan pada masyarakat terjadi dalam pelaksanaan upacara terlihat adanya istilah

\footnotetext{
${ }^{3}$ Hasil wawancara dengan Iwa Permana S.Sen (Pemilik
} MSID), 15 Januari 2020). 
prioritas untuk ibu-ibu majelis taklim maupun orang yang dianggap penting di dalam ruangan pengajian sehingga pemangku hajat biasanya menyiapkan layar $l c d$ di luar agar para ibu yang berada di luar tetap bisa menyaksikan karena di bagian dalam diisi oleh orang-orang penting. ${ }^{4}$

Bahkan peneliti melihat fenomena beberapa ibu yang datang menghadiri pengajian hanya mengobrol atau hanya sekedar menikmati hidangan yang telah diberikan yang merupakan ibu-ibu dari kerabat serta tetangga yang menganggap bahwa pengajian sudah diwakilkan oleh ibu-ibu dari majelis taklim. Dari hal ini dapat dilihat adanya kemerosotan nilai nilai ritual, yang penting hanya datang silaturahmi ke rumah yang mempunyai hajatan.

Setiap ritual upacara selalu melibatkan masyarakat dalam segala hal, akan tetapi seiring perkembangan zaman segala aktivitas masyarakat baik tetangga maupun keluarga yang selalu membantu dalam mempersiapkan peralatan-peralatan seperti bunga setaman ataupun air tujuh sumber untuk upacara sekarang terganti oleh penyedia jasa yang sudah mempersiapkan segala sesuatunya. Sehingga interaksi yang terjadi dalam masyarakat pun juga ikut berkurang. Kebiasaan tersebut terus berlanjut sehingga menjadi masyarakat konsumtif yang mengandalkan materi dalam segala hal termasuk pada upacara-upacara ritus.

Selain itu, dampak dari adanya komodifikasi ini bagi masyarakat, adalah tidak otentiknya bentuk dari tradisi ngaras dan ngibakan ini namun bentuk tersebut dianggap paling benar sehingga menjadi kebenaran sebuah budaya yang telah mengalami pergeseran makna yang berdasar selera pasar; akibat terjadinya manipulasi yang diproduksi oleh industri budaya dengan tujuan agar dibeli di pasar, sehingga melihat pada apa yang dibutuhkan pasar menghasilkan bentuk dari upacara ngaras dan ngibakan ini tergolong kebudayaan semu; terstandarisasinya sebuah upacara ngaras dan ngibakan, sehingga terjadi penyeragaman dalam mekanisme industri budaya yang mana jika tidak berubah mengikuti selera pasar maka akan dianggap

\footnotetext{
${ }^{4}$ Wawancara dengan Roro, Majelis nurul Hidayah (Cipaganti).
}

ketinggalan zaman, hal ini berakibat juga pada penyeragaman harga yang dijadikan patokan oleh para pemilik jasa.

Di mana bagi masyarakat dengan tingkat ekonomi menengah ke atas pelaksanaan ngaras dan ngibakan ini dianggap perlu apalagi dengan bentuk serta rangkaian yang lebih indah dan lebih praktis yang semuanya disediakan oleh pemilik jasa. Sebaliknya bagi masyarakat dengan tingkat ekonomi ke bawah menganggap upacara ini bukan sesuatu yang wajib dilaksanakan sehingga mereka tak perlu lagi mengeluarkan biaya untuk melaksanakan ritual tersebut mereka beranggapan bahwa prosesi akad dan resepsilah yang paling penting dalam sebuah pernikahan dikarenakan harganya yang dianggap mahal. Jika tidak ada upaya dari masyarakat untuk meminimalisir terjadinya perubahan yang terus berlangsung maka generasi-generasi selanjutnya tidak akan mengetahui bagaimana budaya asli yang terdapat di daerahnya.

Menurut peneliti, dari hasil melakukan penelitian di Mitra Seni Inten Dewangga pada upacara ngaras dan ngibakan terhadap komodifikasi yang terjadi menimbulkan kurangnya interaksi sesama warga masyarakat sehingga kurang terjalin kekompakan serta silaturahmi yang kental seperti pada masyarakat dahulu contohnya pada pembuatan dekorasi dan bale yang dulunya dilakukan secara gotong-royong namun sekarang diserahkan pada pemilik jasa.

Hal ini juga merupakan dampak dari perilaku masyarakat yang konsumtif terhadap budaya-budaya atau bentuk-bentuk baru, serta kurangnya pengetahuan tentang pelestarian adat di daerahnya, mengakibatkan budayabudaya lama yang menjadi kebudayaan asli mulai terkikis dan dilupakan, sehingga mungkin masyarakat Sunda khususnya di Kota Bandung selanjutnya tidak pernah tahu tentang bentuk lama dari upacara ngaras dan ngibakan ini.

Selain itu, perubahan yang terjadi juga menjadi masyarakat mulai berpikir bahwa bentuk tersebut yang lebih tepat. Dengan adanya penyedia jasa yang memodifikasi bentuk lama ini menyebabkan masyarakat tidak mau ketinggalan zaman sekaligus kemudahan dan efisiensi pekerjaan pemangku hajat dalam melaksanakan upacara ngaras dan ngibakan ini tanpa melihat berapa biaya yang 
mesti dikeluarkan asalkan sesuai dengan apa yang mereka harapkan.

\section{G. Modifikasi dan Kreativitas Tradisi Ngaras dan Ngibakan}

Terlihat dari dua aspek baik aspek tekstual yang terlihat dengan panca indera maupun kontekstual yang tidak terlihat seperti pada makna yang terkandung di dalamnya. Secara tekstual dapat dilihat dari bentuk serta beberapa rangkaian yang ditambahkan maupun dihilangkan seperti: perubahan pada alat-alat yang digunakan yang awalnya terbuat dari tanah liat diganti dengan peralatan berbahan gelas kristal; perubahan pada tikar pandan yang diganti dengan kain berenda; perubahan pada kain sinjang yang biasanya disusun satu persatu dijahit menjadi lebih panjang; serta penambahan bunga melati dan mawar di setiap peralatan dan air yang digunakan.

Modifikasi pada tradisi ngaras dan ngibakan ini merupakan suatu cara yang digunakan agar dapat memperindah tampilan dan memberikan kesan yang lebih modern dan cantik serta lebih praktis dalam penggunaanya. Contohnya, pada penggunaan peralatan dari gelas kristal dilakukan karena peralatan ini lebih awet dan tidak mudah pecah seperti dari bahan tanah liat sehingga dapat digunakan berulang kali dalam waktu yang sangat lama, bukan itu saja peralatan dari kristal lebih disukai oleh masyarakat saat ini karena dianggap memberi kesan lebih eksklusif. ${ }^{5}$

Selain mengubah bentuk dari peralatan yang digunakan, MSID juga menambahkan beberapa rangkaian yang sebelumnya tidak ada dalam upacara ngaras dan ngibakan ini seperti adanya prosesi menaburkan bunga mawar merah dan mawar putih oleh orang tua, meminumkan air zam- zam, menambahkan prosesi berwudu, pemberian souvenir kepada penyiram calon pengantin, dan prosesi sawer sinjang serta hadiah yang merupakan pengganti dari prosesi rebutan parawanten. Namun demikian, penambahan rangkaian terdapat pula rangkaian prosesi yang dihilangkan karena dianggap terlalu memakan waktu pelaksanaan sehingga seperti pada prosesi menyalakan sumbu, rebutan parawanten, ngeningan, dan potong tumpeng.

\footnotetext{
${ }^{5}$ Hasil Wawancara Iwa Permana (Pemilik MSID ), 12 Maret 2020.
}

Pada rangkaian ngaras dan siraman ini terdapat beberapa rangkaian yang dihilangkan agar lebih efisien hal ini disebabkan permintaan dari keluarga maupun pihak Wedding Organizer yang membatasi waktu pelaksanaan dari pukul 09.00 hingga pukul 12.00 sehingga apabila mengikuti rangkaian lama akan terlalu panjang waktu yang diperlukan. ${ }^{6}$

Modifikasi pada aspek kontekstual dilihat dari nilai-nilai yang terkandung di dalam prosesi ngaras dan ngibakan dapat diketahui terdapat beberapa nilai pada filosofi seperti pada dedaunan atau perubahan peralatan dari tanah liat yang hilang akibat modifikasi namun tidak serta-merta menghilangkan semua konsep serta fungsi aslinya, misalnya dalam prosesi ngaras di mana inti prosesi ini merupakan mencuci kaki oleh pengantin sebagai bentuk nilai rasa hormat dan berbakti pada orang tua masih tetap ada, kemudian cindera-mata yang digunakan atau dimodifikasi merupakan tambahan dari bentuk terima kasih kepada yang mendoakan, sehingga tidak bertentangan dengan nilai-nilai masyarakat Sunda itu sendiri. Meski dalam beberapa prosesi yang dihilangkan terdapat pesan yang cukup penting bagi calon pengantin. Dilihat dari perubahan-perubahan tersebut maka hal ini sesuai dengan pengertian modifikasi menurut Lutan (1998:2) di mana modifikasi sebagai perubahan keadaan, dapat berupa bentuk, isi, fungsi, cara penggunaan dan manfaat tanpa sepenuhnya menghilangkan aslinya. Di mana dalam upacara ngaras dan ngibakan dilakukan perubahan ke arah lebih maju atau lebih sesuai baik bentuk cara penggunaan serta fungsi tanpa sepenuhnya menghilangkan rangkaian inti pada tradisi tersebut.

\section{H. Komodifikasi Tradisi Ngaras dan Ngibakan pada MSID}

Prosesi upacara ngaras dan ngibakan yang berlaku sekarang merupakan sebentuk kreativitas modifikasi dari MSID yang merupakan bentuk perkembangan berdasar pada upacara ngaras dan ngibakan yang sudah ada sebelumnya dalam masyarakat Sunda di Kota Bandung, di mana pada pelaksanaanya dilakukan proses rekonstruksi atau penyusunan kembali dengan menambahkan hal- hal baru

\footnotetext{
${ }^{6}$ Hasil Wawancara Iwa Permana (Pemilik MSID ), 12 Maret 2020.
} 
agar lebih menarik, praktis, dan efisien yang merupakan suatu cara agar upacara ngaras dan ngibakan ini laku di pasar dengan mengikuti apa yang diinginkan oleh masyarakat sehingga bukan hanya dilihat dari segi nilai guna tetapi juga dilihat dari nilai tukarnya di pasar maka dapat dikatakan bahwa inovasi-inovasi tersebut merupakan kemampuan untuk menerapkan kreativitas dalam rangka menemukan peluang (doing newthing) pada pasar. Hal ini sejalan dengan teori komodifikasi yang mengidentifikasi keberadaan komoditas yang sangat mempertimbangkan daya tarik, agar bisa dipuja oleh orang sebanyak-banyaknya yang bermuara pada nilai jual di pasar.

Nilai komoditi dapat dilihat dari adanya nilai guna yang dijadikan nilai tukar di mana pada tradisi ngaras dan ngibakan yang tadinya digunakan untuk memenuhi kebutuhan pelaksananya, baik itu kebutuhan secara batiniah maupun sebagai bentuk mempertahankan tradisi menjadi sebuah tradisi yang memiliki nilai tukar di mana seluruh sarana dan prasarana disiapkan oleh pemilik jasa, nilai tukar tersebut didasarkan pada nilai ekuivalen sehingga dapat dijadikan nilai komoditi maksimal oleh MSID ketika memodifikasi peralatan serta rangkaian yang digunakan dalam upacara dengan bentuk baru maka para pemangku hajat bersedia untuk memberikan nilai tukar lebih karena dianggap lebih bagus dan praktis. Seperti yang dijelaskan di atas bila dimasukan ke dalam rumus komoditas Marx (dalam Suseno, 2016:196) $\mathrm{M} 1<\mathrm{K}<\mathrm{M} 2$, maka modal awal yang dikeluarkan akan lebih sedikit karena terdapat beberapa bagian yang dihilangkan serta perubahan peralatan dari tanah liat menjadi gelas kristal yang lebih tahan lama serta modifikasi menyebabkan masyarakat lebih tertarik sehingga dapat menghasilkan nilai komoditas maksimal maka dari proses inilah komodifikasi terjadi pada upacara ngaras dan ngibakan.

\section{SIMPULAN}

Penelitian tentang komodifikasi upacara ngaras dan ngibakan pada Mitra Seni Inten Dewangga yang telah diuraikan dalam bagian sebelumnya dapat diambil beberapa simpulan, yaitu:

\section{A. Prosesi rangkaian upacara}

Ngaras dan ngibakan yang terdapat pada Mitra Seni Inten Dewangga saat ini, merupakan bentuk perubahan atau modifikasi dari bentuk asli yang sudah ada sebelumnya, yang kemudian ditambahkan baik hal-hal yang berbentuk baru maupun dipadatkan yang disesuaikan dengan perkembangan zaman agar lebih menarik dan memiliki nilai jual yang tinggi bagi penyedia jasa. Perubahan yang terjadi akibat komodifikasi dalam upacara ngaras dan ngibakan ini terlihat pada bentuk dekorasi, peralatan yang digunakan, serta rangkaian yang ditambahkan dan dihilangkan sehingga memangkas waktu pelaksanaan juga memperindah rangkaian tersebut.

\section{B. Dampak komodifikasi pada masyarakat}

Pengguna jasa ngaras dan ngibakan ini menganggap bahwa perubahan yang terjadi pada masa sekarang ini, dianggap lebih sesuai dan lebih praktis di mana pihak keluarga tidak perlu lagi memikirkan semua perlengkapan karena sudah disiapkan oleh penyedia jasa dengan kata lain perubahan tersebut pada masyarakat ini diterima dan bahkan diharapkan oleh masyarakat, namun di sisi lain nilai-nilai kebersamaan dan gotong-royong semakin hilang. Kemudian adanya penyeragaman bentuk dari para pemilik jasa yang berdampak pada penyeragaman harga mengakibatkan masyarakat kelas bawah tidak lagi melaksanakan upacara tradisi ngaras dan ngibakan ini karena dianggap mahal sehingga dijadikan sesuatu yang sunnah.

\section{DAFTAR PUSTAKA \\ Buku}

Abdulsyani.(2002).Sosiologi

Skematika,Teoridan Terapan. Jakarta . PT Bumi Aksara.

Barker, Chris. (2013). Cultural Studies. Teori \& Praktik,

Penerjemah:Nurhadi.Yogyakarta:

KreasiWacana.

Evans, D. (2004). Das kapital Untuk Pemula. Yogyakarta: Resist Book.

Karl Marx. (2004). Kapital Jilid 1, sebuah kritik ekonomi politik. Yogyakarta: Hasta Mitra

Lutan, Rusli. (1988). Belajar Ketrampilan Motorik: Pengantar Teori dan Metode. 
LPTK. Jakarta

Magnis, Suseno. (2016). Pemikiran Karl Marx: Dari sosialisme utopis ke perselisihan revisionisme. Jakarta: PT. Gramedia.

Manan, Imran (1989) Perubahan Sosial Budaya, Modernisasi dan Pembangunan dalam Dasar - dasar Sosial Budaya Pendidikan, Jakarta: P2LPTK

Moleong, L. J. (2012). Metodologi Penelitian Kualitatif. Bandung: Remaja Rosda Karya.

Ngalimun,dkk.(2013). Perkembangan dan Pengembangan Kreativitas. Yogyakarta: Aswaja Pressindo

Rusli Lutan, (1998). Belajar Ketrampilan Motorik, Pengantar Teori dan Metode. Departemen P\&K Dirjen Dikti Proyek Pengembangan Lembaga Pendidikan dan Tenaga Kependidikan.Jakarta

Rosidi. A, Ekadjati, E.S, Chaedar A. (2006). Konferensi internasional Budaya Sunda. Bandung: Yayasan Kebudayaan Rancage \& PT. Kiblat Buku Utama.

Soekanto, Soerjono. (2006). Sosiologi Suatu Pengantar. Jakarta: Raja Grapindo Persada.

Suhendi. (2004). Tata Rias Pengantin Sunda Putri. Jakarta: Meutia Cipta Sarana.

Sukmadinata, N. S. (2012). Metode Penelitian Pendidikan. Bandung: PT. Remaja Rosdakarya.

Suryalaga, H. (1997). Rineka Budaya Sunda
(Kumpulan Karangan). Bandung: CV. Geger Sunten.

Syam, N. (2005). Islam Pesisir. Yogyakarta: LKis Pelangi Aksara.

Wicaksono, Soetam Rizky, (2018). Antologi Teknologi Informasi: Tinjauan Manajemen Sumber Daya Manusia. Malang: Seribu Bintang

\section{Jurnal}

Dewi,A.P.(2016).Komoditas Tari Barong di Pulau Bali. Jurnal Panggung. Hal. 222.

Hayati, I. (2019). Mengapa harus ada siraman. Jurnal Etnis.

\section{Skripsi dan Tesis}

Hadiati. (2016). Bentuk makna dan fungsi upacara ritual daur hidup manusia pada masyarakatsunda.Surabaya:Universitas Airlangga.

Lerina, Wina. (2015). Garapan Penyajian Upacara Siraman calon Pengantin Adat Sunda Group Swari Laksmi KabupatenBandung. Bandung: UPIBandung.

Triana, Ana. (2017). Ajaran Berbakti kepada Orang tua dalam Tembang-tembang Upacara Ngaras. Bandung: UPI Bandung.

Yulianti. (2011). Upacara Religi dan Pemasaran Pariwisata: Studi Tentang Komodifikasi Tabot Di Propinsi Bengkulu. Surakarta: UNSPascasarjana. 